\title{
Autotransplant of Spleen Tissue in Children with Schistosomiasis: Evaluation of Splenic Function after Splenosis
}

\section{Carlos Teixeira Brandt ${ }^{+}$, Dione Tavares Maciel, Oyama Arruda Frei Caneca, Célia Maria Machado Barbosa de Castro, Lenísio Bragante de Araújo}

\author{
Departamento de Cirurgia, Hospital das Clínicas, CCS, Universidade Federal de Pernambuco, Av. Moraes Rego \\ s/no, 50670-420 Recife, PE, Brasil
}

Autotransplantation of spleen tissue has been done, in the past ten years, in children with schistosomiasis mansoni with bleeding varices. The purposes of this investigation were: (1) to study the morphology and function of the remnant spleen tissue; (2) to quantify the production of tuftsin; and (3) to assess the immune response to pneomococcal vaccine of these patients. Twenty three children, who underwent splenectomy and autologous implantation of spleen tissue into the greater omentum were included in this investigation. The average postoperative follow-up is five years. Splenosis was proved by colloid liver-spleen scans. Search for Howell-Jolly bodies assessed the filtration function. Tuftsin and the titer of pneumococcal antibodies were quantified by ELISA. Splenosis was evident in all children; however, it was insufficient in two. Howell-Jolly bodies were found only in these two patients. The mean tuftsin serum concentration $(335.0 \pm 29.8 \mathrm{ng} / \mathrm{ml})$ was inside the normal range. The immune response to pneumococcal vaccination was adequate in 15 patients; intermediate in four; and inadequate in four. From the results the following conclusions can be drawn: splenosis was efficient in maintaining the filtration splenic function in more than $90 \%$ and produced tuftsin inside the range of normality. It also provided the immunologic splenic response to pneumococcal vaccination in $65 \%$ of the patients of this series.

Key words: spleen tissue autotransplantation - splenosis - Schistosoma mansoni splenic functions - tuftsin pneumococcal vaccine response

Schistosomiasis mansoni is hyperendemic in northeastern Brazil, representing the main cause of portal hypertension in children (Kelner 1992, Amaral $\&$ Porto 1994). The hepatosplenic form of this disease with bleeding esophageal varices is not common in children (Kelner 1992). However, if occurs, it may determine severe implications of their whole productive life.

Splenectomy, ligature of the left gastric vein and sclerosis of the esophageal varices is one of the most frequent surgical treatment for the upper digestive hemorrhage associated with portal hypertension from hepatosplenic schistosomiasis mansoni (Kelner 1992, Lacerda et al. 2000). In children, auto-implantation of spleen tissue into a pouch of the greater omentum has been added to this protocol as way to protect against overwhelming postsplenectomy sepsis (OPSI). However de-

\footnotetext{
${ }^{+}$Corresponding author. Fax: $+55-81-3342-0830$. E-mail: carlosbrandt@bol.com.br

Received 14 May 2001

Accepted 25 July 2001
}

creasing the portal inflow to the liver, this surgical approach has proved to decrease the portal hypertension, to improve the somatic development of these children as well as to maintain the hepatic functional reserve (Brandt et al. 1995, 1997).

King and Schumacker (1952) drew attention to the risks of OPSI after splenectomy in children. Subsequent reports have confirmed these observations and have changed the concept of the spleen as an unessential organ. Without the filtering function of the spleen, pneumococcus and other organisms may rapidly multiply in the bloodstream causing OPSI (Hays et al. 1986, Traub et al. 1987, Steely et al. 1988).

Immunization with pneumococcal, meningococcal and hemophilus vaccines are efficacious in the prevention of OPSI if they are given two weeks before splenectomy. Prophylaxis with oral penicillin V should be considered in splenectomized patients without splenosis. In patients who had undergone splenectomy, due to trauma, without previous vaccination but develop natural splenosis or autologous splenic implantation, the immunization with pneumococcal polysaccharides appears to produce good specific antibody response (Weibel 
et al. 1977, Aargerge et al. 1984, Hathaway et al. 1995).

Tuftsin, a physiological phagocytic stimulating peptide, produced only by the spleen, stimulates the phagocytosis, mobility, immunogenic and bactericidal activity; and maintains a significant correlation with residual splenosis after splenectomy due to trauma (Nishioka et al. 1972, Zolli et al. 1994, Zvi et al. 1997).

Natural splenosis or intentional autologous spleen tissue implantation have been controversial in adults, although in children have been used to explain the lesser risk of OPSI in the normal splenectomized host (Velcek et al. 1982, Patel et al. 1986, Westermann \& Pabst 1986, Kays et al. 1993, Müller et al. 1995).

The purpose of this investigation was: to investigate the results of spleen tissue implantation in the greater omentum in children and adolescents with portal hypertension due to schistosomiasis after undergoing splenectomy and ligature of the left gastric vein; to evaluate the residual filtration function of the implanted spleen tissue; to quantify the production of tuftsin; and to assess the immune response to pneumococcal vaccine of these patients.

\section{MATERIALS AND METHODS}

Patients - Twenty three patients, from 11 to 18 years of age, 17 males and 6 females, suffering from recurrent upper digestive bleeding associated with severe portal hypertension due to hepatosplenic schistosomiasis mansoni were included in this investigation. All of them had undergone splenectomy, ligature of the left gastric vein and auto-implantation of ten slices of spleen tissue, without the capsule, into an omental pouch in the greater omentum. The measurements and weights of the implanted slices were approximately: 3 x $2 \times 2 \mathrm{~cm}$ and $10 \mathrm{~g}$ each.

Patients presenting recurrent upper digestive hemorrhage in the follow-up were included in the protocol for endoscopic sclerosis of esophageal varices. All patients were cared for at the University Hospital (Hospital das Clínicas), Federal University of Pernambuco, Brazil, from 1990 to 1999.

The patients were treated, 30 days before surgery, with oxamniquine for the schistosomiasis in a single dose of $20 \mathrm{mg} / \mathrm{kg}$, up to a total dose of 600 $\mathrm{mg}$. Liver function tests and serum investigation for hepatitis B antigenemia were done in all of them. The Child's criteria for assessment of hepatic functional reserve were used. Eighteen patients were Child A and 5 were Child B.

Routine wedge liver biopsies from all patients, taken at the time of surgery, were sent for histopathology. Symmers' fibrosis grade III was observed in 18 patients; 4 were grade II; and 1 grade I. Moderate grade $(++/++++)$ of portal inflammatory activity was observed in 16 patients; and fair grade $(+/$ $++++)$ was observed in 7 patients. Important $(+++/$ ++++ ) portal granulomatous activity was observed in 3 patients; moderate $(++/++++)$ in 3 patients; and in 8 a fair $(+/++++)$ grade of granulomatous activity was observed. Nine patients presented with no portal granulomatous activity. Minimal schistosomotic pigmentation in the hepatic portal space was observed in 5 patients; and moderate in 1, however, in 17 patients, such pigmentation was not observed.

Splenosis - The patients were assessed for splenic nodules (splenosis) using the hepatosplenic nuclear scan, employing sulfur colloidal preparations labeled with technetium ${ }^{99 \mathrm{~m}}$, administered intravenously in a single dose of $7 \mathrm{mCi}$. These routine evaluations were done six months and one year after surgical treatment.

Splenic filtration function - After an average follow-up of one year peripheral blood smears were examined in all patients for the presence of HowellJolly bodies, using the Giemsa staining. These investigation was used to assess the hemocateretic splenic function. The presence of Howell-Jolly bodies was accepted as absence or insufficiency of this function.

Tuftsin concentration - Fourteen, out of those 23 three patients, were evaluated for the tuftsin serum concentration. Six of them had had also evaluation before surgical treatment. As a local standard of normality, four children from the same geographic area and similar nutritional status, without schistosomiais mansoni, were used as a control group.

The tuftsin concentration was measured, in the serum, by ELISA. The rabbit antiserum was prepared after immunization with a bovine-albumintuftsin conjugate. For the serum sample tetrapeptide quantification, the dry extracts of tuftsin were obtained after serum tripsinization. After this step, the dry extracts underwent hydration with $500 \mu \mathrm{l}$ of PBS-Tween 0.01M. From this solution, $50 \mu \mathrm{l}$ were incubated with $50 \mu \mathrm{l}$ of rabbit antiserum at $37^{\circ} \mathrm{C}$, with a final dilution of 1:15,000. After $1 \mathrm{~h}$ of incubation in glass tubes, the samples were transferred to microtitulation plates previously coated with bovine-albumin-tuftsin conjugate. After a second incubation for $1 \mathrm{~h}$ at $37^{\circ} \mathrm{C}$, the plates were washed with the PBS-Tween and a second antibody conjugated with peroxidase was added. Following, it was revealed and processed for the development of the staining. After that, a double reading of the plate content optical densities were done. The readings were compared with the values of a synthetic tuftsin standard curve which values ranged from 50 a 500 $\mathrm{ng} / \mathrm{ml}$. 
Pneumococcal vaccination - All patients received $0.5 \mathrm{ml}$ of intramuscular polyvalent pneumococcal vaccine (Pneumo 23-Pasteur MérieuxFrance). Before vaccination and after six weeks blood samples were collected. Pre and post immunization serum samples were used for ELISA, in the same plates, of pneumococcal type-specific polysaccharide antibody responses. The results were expressed in fold increase of titer antibody immune response, defined as FI = postimmunization titter over preimmunization titter. FI is defined by the following equation: $\mathrm{FI}=2\left(\log 10^{\mathrm{b}}-\log 10^{\mathrm{a}}\right) / \mathrm{m}$, where $a$ is the extinction of the prevaccination sample; $b$ is the extinction of the postvaccination sample; and $\mathrm{m}$ is the difference between $\log 10$ values of two consecutive twofold dilutions of the standard serum against $\log 10$ (extinction $\times 10^{2}$ ) of the same serum.

The patients who presented with FI greater than two were considered normal as regard to their immune response. Patients with FI between one and two were accepted as presenting intermediate response, and the ones with FI smaller than one were considered with impaired immune response.

Statistical analysis and ethical considerations - The quantitative results were expressed by their means and standard deviations. The paired and unpaired Student " $t$ " tests were used for measuring the difference among means; $p<0.05$ was used to reject the null hypothesis.

The wedge liver biopsy was done in all patients as an essential part of proving the severity of schistosomiasis mansoni, as well as to exclude any other liver disease. Vaccination against pneumococcus is mandatory in patients who had undergone splenectomy and have developed splenosis without receiving this immune stimulus prior to surgery. On the other hand, the local ethical committee approved this study.

\section{RESULTS}

Splenosis - Hepatosplenic Tc-99m scan demonstrated five or more splenic nodules in the greater omentum in $21(91.3 \%)$ out of the 23 patients (Figure). They were considered as having sufficient residual spleen tissue. However, in two patients $(8.7 \%)$ less than five splenic nodules were identified.

Splenic filtration function - Absence of HowellJolly bodies was observed in $21(91.3 \%)$ out of the 23 patients. In two (8.7\%) patients, with less than five splenic nodules identified in the scintigraphic scan, Howell-Jolly bodies were found in their peripheral blood smears.

Immune response to pneumococcal vaccine The mean post-immunization serum concentration of pneumococcal antibodies was greater than the pre-immunization (" $\mathrm{t}$ " $=2.74 ; \mathrm{p}<0.01$ ). Fifteen patients $(65.2 \%)$ presented with FI greater than two. In four patients $(17.4 \%)$ the FI were between one and two and in another four patients (17.4\%) the FI remained bellow one.

Serum concentration of the tuftsin activity The tuftsin postoperative mean serum concentration $(335.0 \pm 29.8 \mathrm{ng} / \mathrm{ml})$ was similar to the control group $(282.0 \pm 71.6 \mathrm{ng} / \mathrm{ml})$. In the six patients evaluated before treatment the tuftsin serum concentrations were, always, higher than $500 \mathrm{ng} / \mathrm{ml}$, well over the superior limit of the calibration curve (Table).

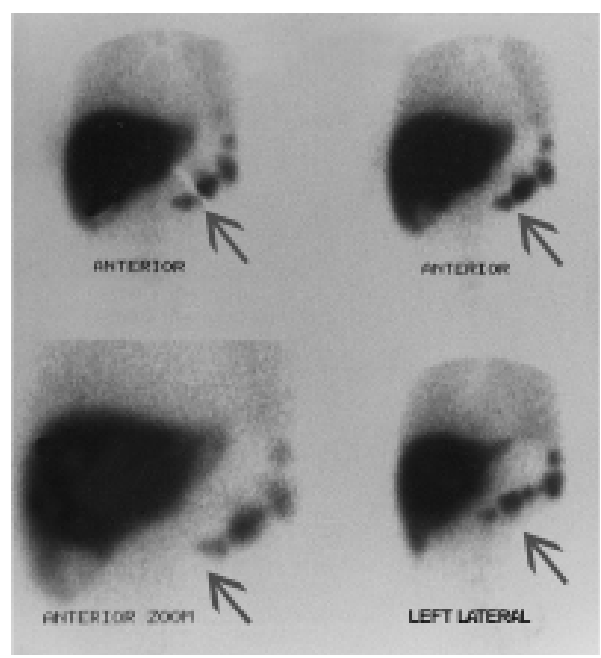

Sufficient splenosis. Five splenic nodules seen in the left lateral view.

\section{TABLE}

Tuftsin serum concentrations before and after surgical treatment

\begin{tabular}{ccc}
\hline $\begin{array}{c}\text { Postoperative } \\
\mathrm{ng} / \mathrm{ml}\end{array}$ & $\begin{array}{c}\text { Preoperative } \\
\mathrm{ng} / \mathrm{ml}\end{array}$ & $\begin{array}{c}\text { Control } \\
\mathrm{ng} / \mathrm{ml}\end{array}$ \\
\hline 290 & $\Uparrow 500$ & 280 \\
420 & $\Uparrow 500$ & 100 \\
280 & $\Uparrow 500$ & 300 \\
220 & $\Uparrow 500$ & 450 \\
400 & $\Uparrow 500$ & \\
400 & $\Uparrow 500$ & \\
300 & & \\
280 & & \\
290 & & \\
300 & & \\
280 & & \\
300 & & \\
460 & & \\
\hline $\mathrm{X}_{1}=335.0 \pm 29.8$ & $\mathrm{X}=\Uparrow 500$ & $\mathrm{X}_{2}=282.0 \pm 71.6$ \\
"t" $\left(\mathrm{X}_{1}\right.$ versus $\left.\mathrm{X}_{2}\right)=1.44-\mathrm{p}>0.05$ & \\
\hline
\end{tabular}




\section{DISCUSSION}

It has been observed, after total splenectomy in children, a low but worrying prevalence of OPSI, especially due to encapsulated bacteria, such as pneumococcus. Elective removal of the spleen after trauma produces a series of important changes in the immune system, including deficiency in phagocytosis. The overall incidence of OPSI is about $4.25 \%$, but varies with age and underlying diseases (Mollitt \& Dokler 1997). Partial splenectomy, splenorraphy, partial splenic embolization and autologous splenic implantation in the greater omentum have been used for minimizing the risks of OPSI. Prophylactic penicillin is routinely employed after splenectomy in children to protect against pneumococcal infection. On the other hand, preventive vaccination against pneumococcus and other pathogens have been used more frequently in asplenic patients (Kays et al. 1993 ).

Natural splenosis, reported after splenectomy, due to trauma, in about $34 \%$ of the patients, or intentional splenosis, seem to reduce the adverse effects caused in the immune system. However controversial, the maintenance, at least in part, of the phagocytic activity in the neo-formed spleen nodules and the preservation of immune memory may recommend autologous splenic implantation after inevitable splenectomy (Velcek et al. 1982, Patel et al. 1986, Westerman \& Pabst 1986, ShokouAmiri et al. 1990, Müller et al. 1995). Nevertheless, the effective ability of the splenosis to protect the host against encapsulated microorganisms is still challenged (Cooney et al. 1979, Rice \& James 1980, Tesluk et al. 1984, Loogie \& Hinchey 1986, Green et al. 1986, Hays et al. 1986).

The immune response capacity, after human splenic autotransplantation following splenectomy due to trauma, is maintained for pneumococcal vaccine subtypes (Leemans et al. 1999). However, this kind of response had not yet been investigated in patients with portal hypertension due to hepatosplenic schistosomiasis mansoni infection.

Total splenectomy in human beings is followed by losses of the ability to generate tuftsin, a splenic endocarboxipeptidase (Nishioka et al. 1972, Zvi et al. 1997). Maintenance of serum tuftsin levels in the lower limits of normality is observed in patients who had undergone splenectomy after trauma, but intentional or unintentional tissue spleen implantation occurs in the abdominal cavity. There are also, in these patients, a negative correlation between the percentage of Howell Jolly bodies in the peripheral blood smear and tuftsin activity, proving that residual splenic activity is kept in those patients (Zoli et al. 1994). The protector effect of synthetic tuftsin has been proved in the experi- mental sepsis after total splenectomy (Chu et al. 1985).

In children with huge splenomegaly, portal hypertension and bleeding esophageal varices due to schistosomiasis mansoni infection, autologous implantation of spleen tissue from the upper pole into an omental pouch of the greater omentum after splenectomy and ligature of the left gastric vein is still under investigation. The clinical observations of the 64 children with this condition who entered in this protocol, from January 1990 to March 2000, cared for at The University Hospital, Federal University of Pernambuco, Brazil, are very encouraging. There has been no increase in the rate of infection and it was observed no case of OPSI (Brandt et al. 1997).

The radioisotope evidence, on over one year follow-up, in 21 out of 23 patients of more than five splenic nodules shows that autologous splenic implantation into an omental pouch in the greater omentum is more effective than natural splenosis for maintaining functioning splenic parenchyma. However, in two patients $(8.7 \%)$ there were less than five splenic nodules both of them were positive for Howell Jolly bodies. This seems to indicate that the splenic filtration function is associated with the amount of remaining spleen tissue. Previous study on partial splenic embolization in children, with portal hypertension due to congenital abnormalities, showed that the remaining $15 \%$ to $25 \%$ of pre-treatment splenomegaly was sufficient to maintain normal hemocatheretic splenic function (Brandt et al. 1989).

Normal specific anti-pneumococcal antibody response in $65 \%$ of the patients in this series may represent the efficacy of the residual spleen tissue in maintaining the immune humoral defense. This may be the result of the preservation of the B lymphocyte memory. We have already demonstrated an increase in B lymphocytes after splenectomy and autologous spleen tissue implantation in the major omentum in children with surgical schistosomiasis (Brandt et al. 1995). Among the eight patients with intermediate and impaired immune response two had inefficient splenosis, other two had pre-immunization high levels of antipneumococcal antibodies and four were positives for hepatitis B. All of them were considered as moderate risk (B) for the hepatic functional reserve. As a general rule the patients with normal immune response had sufficient splenosis, were negative for hepatitis B, with pure Symmers fibrosis on liver biopsy and were considered as good risk (A) for the hepatic functional reserve.

Similarly to the reports of spleen function preservation after unintentional splenosis following splenectomy for trauma the present investigation 
confirms normal serum tuftsin concentrations in children with hepatosplenic surgical schistosomiasis mansoni who had undergone splenectomy, ligature of the left gastric vein and autologous implantation of spleen tissue in the major omentum. These findings are originals and support the principles that autologous spleen tissue implantation after splenectomy in children should be mandatory. On the other hand, excessive serum concentrations of tuftsin before surgery in the patients of this investigation are in agreement with the high levels of immunglobulin $G$ in these children. It should be stressed that after surgical treatment these patients show important decrease of serum immunglobulin $\mathrm{G}$ levels, even though they still remain over the normal limit range, similarly as it happens with tuftsin.

We have showed that although the majority of these patients present Symmers' fibrosis grade III (Brandt et al. 2000) they maintain good hepatic functional reserve which seems to be important in the immune response. It is likely that positive antigenemia for hepatitis prior to surgery and/or liver cirrhotic changes, and poor hepatic functional reserve may have impaired the residual splenic functions in some patients who are considered to have non pure $S$. mansoni disease. On the other hand, inefficient splenosis seemed to be associated with surgical technical failure.

From the results the following conclusions can be drawn: splenic filtration and immuneresponse to pneumococcal vaccination can be achieved, in the majority of the children with severe portal hypertension due to hepatosplenic schistosomiasis mansoni, who have undergone splenectomy followed by efficient autologous implantation of spleen tissue in the greater omentum. Also, this method is effective in maintaining the serum tuftsin concentration inside the range of normality.

\section{REFERENCES}

Aargerge IS, Heier HE, Hem E, Giercksky Y, Grong EC 1984. IgM and $\operatorname{IgG}$ response to pneumococcal polysaccharide vaccine in normal individuals and individuals splenectomyzed due to trauma. Acta Path Microbiol Immunol Scand Sect 92: 11-16.

Amaral RS, Porto AS 1994. Evolução e situação do controle da esquistossomose no Brasil. Rev Soc Bras Med Trop 27: 73-89.

Brandt CT, Domingues ALC, Figueredo-Silva J, Jucá N, Aguiar JLAA, Domingues LAW 2000. Esquistossomose hepatoesplênica cirúrgica: histopatologia hepática e endoscopia digestiva alta em crianças comparadas a adultos. Rev Col Bras Cir 27: 13-18.

Brandt CT, Rothbarth LJ, Kumpe D, Karrer FM, Lilly JR 1989. Splenic embolization in children: long-term efficacy. J Pediatr Surg 24: 642-644.

Brandt CT, Tavares DJS, Caneca OAF 1997. Splenec- tomy associated with ligature of the left gastric vein in children with surgical schistosomiasis: analysis of the hepatic functional reserve. Acta Cir Bras 8: 150153.

Brandt CT, Tavares DJS, Caneca OAF, Ávila Jr L 1995. Surgical hepatosplenic mansonic schistosomiasis in children: a Doppler Duplex study of the portal vein and hepatic artery. Trans R Soc Trop Med Hyg 89: 70-71.

Chu DZJ, Nishioka K, El-Hazin T, Hopfer RL, Romsddahl MM 1985. Effects of tuftsin on postsplenectomy sepsis. Surgery 97: 701-706.

Cooney DR, Dearth JC, Swanson SE, Dewanjee MK, Telander RC 1981. Preservation of splenic function by autotransplantation of traumatized spleen in man. Surgery 90: 683-688.

Green JB, Shackford SR, Sise MJ, Powell RW 1986. Postsplenectomy sepsis in pediatric patients following splenectomy for trauma: a proposal for a multi-institutional study. J Pediatr Surg 21: 10841086.

Hathaway JM, Harley RA, Sally S, Schiffman G, Virella G 1995. Immunological function in post-traumatic splenosis. Clin Immunol Immunopathol 74: 143-150.

Hays DM, Ternberg JL, Chen TT, Sullivan MP, Tefft M, Fung F, Gilchrist G, Fryer C, Gehan EA 1986. Postsplenectomy sepsis and other complications following staging laparotomy for Hodgkin's disease in childhood. J Pediatr Surg 21: 628-632.

Kays MA, Stolar CJH 1993. The spleen and splenectomy: implications for pediatric population. In Fonkalsrud EW, Krummel TM (eds), Infections and Immunologic Disorders in Pediatric Surgery, WB Saunders Co., Harcourt Brace Jovanovich, Inc., Philadelphia, London, Toronto, Montreal, Sydney, Tokyo, p. 91-100.

Kelner S 1992. Critical evaluation of surgical treatment of schistosomotic portal hypertension. Mem Inst Oswaldo Cruz 87: 357-368.

King H, Schumacker HB 1952. Splenic studies: susceptibility to infection after splenectomy performed in infancy. Ann Surg 136: 239-242.

Lacerda CM, Evangelista Neto J, Melo PSV 2000. Hemorragia por varises esofágicas: aspectos atuais. An Fac Med Univ Fed Pernamb 45: 57-68.

Leemans R, Manson W, Snijder JA, Smit JW, Klasen HJ, Timens W 1999. Immune response capacity after human splenic autotransplantation: restoration of response to individual pneumococcal vaccine subtypes. Ann Surg 229: 279-285.

Loggie BW, Hinchey J 1986. Does splenectomy predispose to meningococcal sepsis? An experimental study and clinical review. J Pediatr Surg 21:326-330.

Mollitt DL, Dokler ML 1997. Spleen. In KT Oldham, PM Colombani, RP Foglia (eds), Surgery of Infants and Children: Scientific Principles and Pratice. Lippincot-Raven, Publishers, Philadelphia, New York, p. 1425-1436.

Müller U, Rothlin M 1995. Splenic neoformation following trauma-induced after splenectomy: diagnosis and function. Swiss Surg 5: 230-535.

Nishioka K, Constantopoulos A, Statoh PS, Najjar VA 
1972. The characteristics isolation and synthesis of the phagocitosis stimulation peptide tuftsin. Biochem Biophys Res Commum 47: 172-179.

Patel J, Williams JS, Naim JS, Hinshaw JR 1986. The effect of site and technique of splenic tissue reimplantation on pneumococcal clearance from the blood. J Pediatr Surg 2: 877-880.

Rice HM, James PD 1980. Ectopic splenic tissue failed to prevent fatal pneumococcal septicemia after splenectomy for trauma. Lancet 15: 565-566.

Shokouh-Amiri MH, Kharazml A, Rahimi-Saber S, Hansen CP, Jensen SL 1990. Phagocyte function after splenic autotransplantation. Arch Surg 125: 595-597.

Steely WM, Satava RM, Brigham RA, Setser ER, Davies RR 1998. Splenic autotransplantation: determination of the optimum amount required for maximum survival. J Surg Res 45: 327-332.

Tesluk GC, Thomas CG, Benjamin JT, McMillan C 1984. Fatal overwhelming postplenectomy sepsis following autologous splenic transplantation in severe congenital osteopetrosis. J Pediatr Surg 19: 269-272.

Traub A, Giebink GS, Smith C, Kuni CC, Brekke ML, Edlund D, Perry JF 1987. Splenic reticuloendothe- lial function after splenectomy, spleen repair and spleen autotransplantation. N Engl J Med 317: 15591564.

Velcek FF, Jongco B, Shaftan GW, Klotz DH, Rao SP, Schiffman G, Kottmeir PK 1982. Posttraumatic splenic reimplantation in children. J Pediatr Surg 12: 879-883.

Weibel RE, Vella PP, Mclaren AA, Woodhour AF, Davidson WL, Hilleman MR 1977. Studies in human subjects of polyvalent pneumococcal vaccines. Proc Soc Exp Bio Med 156: 144-150.

Westermann J, Pabst R 1986. Autotransplantation of splenic fragments: lymphocyte subset in blood, lymphonodules and splenic tissue. Clin Exp Immunol 64: 188-194.

Zolli G, Corazza GR, D’amato G, Bartolli R, Baldoni F, Gasbarrini G 1994. Splenic autotransplantation after splenectomy: tuftsin activity correlates with residual splenic function. British J Surg 81: 716-718.

Zvi S, Zakuth V, Diamant S, Mondorf W, Stefanescu T, Stabinski Y, Fridkin M 1977. Decreased tuftsin concentrations in patients who have undergone splenectomy. British Med J 2: 1574-1576. 